\title{
İlkokul Öğrencilerinin Kuvvet Kavramına İlişkin Algılarının Çizim Yardımı ile Belirlenmesi
}

\author{
DOI: 10.26466/opus.937992
}

\author{
* \\ Mustafa Çoramık ${ }^{*}$ - Erdoğan Özdemir ** \\ * Araş. Gör. Dr., Balıkesir Üniversitesi, Necatibey Eğitim Fakültesi, Balıkesir/Türkiye \\ E-Posta: mustafacoramik@balikesir.edu.tr ORCID: 0000-0002-3225-633X \\ ** Dr. Öğr. Üyesi, Sivas Cumhuriyet Üniversitesi, Sağlık Hizmetleri MYO, Sivas/Türkiye \\ E-Posta: erdoganozdemir@cumhuriyet.edu.tr $\quad$ ORCID: 0000-0001-7943-8002
}

Öz

Fiziğin gelişimindeki dönüm noktalarından birisi de Newton'un kuvvet hareket ilişkisini tanımlayan yasaları oluşturmasıdır. Fizik dersinin anlaşılması için kuvvet kavramının ve kuvvet hareket ilişkisinin anlaşılması önemlidir. Bu nedenle, ilköğretimden itibaren Fen Bilimleri Dersi Öğretim Programlarında kuvvet ve hareket konusuna yer verilmektedir. Alanyazın incelendiğinde ise öğrencilerin fiziksel olaylar günlük tecrübeleri ile açıklama eğiliminde oldukları ve ilkçağ düşünürlerinin kuvvet ve hareket ile ilgili fikirlerine benzeyen fikirlere sahip oldukları görülmektedir. Bu araştırmada küçük yaş grubundaki öğrencilerin kuvvet ile ilgili algılarının belirlenmesi amaçlanmıştır. Bu amaçla nitel araştırma desenlerinden birisi olan olgubilim (fenomenoloji) kullanılmıştır. Araştırmaya 2019-2020 eğitim öğretim yılının güz döneminde (Aralık/2019) öğrenim görmekte olan 113 ilkokul 4. simı öğrencisi katılmıştır. Veriler öğrencilerin kuvvet kavramı çizimleri ve açıklamaları yardımı ile toplanmıştır. Öğrencilerin kuvvet ile ilgili çizimleri içerik analizi kullanılarak analiz edilmiştir. Analiz sonucunda öğrencilerin kuvvet algıları hakkında bilgi veren tema, kategori ve kodlar belirlenmiştir. Araştırma sonuçlarına göre öğrencilerin kuvvet ile ilgili algılarmın kapsamlı olduğu fakat bu algıda güçlendirilmesi gereken noktalarm olduğu tespit edilmiştir. Araştırma sonuçları göz önünde bulundurularak öğretmenlere sını ortamında ve Covid-19 salgını sırasında uzaktan eğitim derslerinde uygulayabilecekleri somut etkinlikler önerilmiştir.

Anahtar Kelimeler: Fen Eğitimi, Kuvvet Algısı, Fizik Eğitimi, Nitel Analiz, Olgu Bilim. 


\title{
Determination of Primary School Students' Perceptions about Force with the Help of Drawing
}

*

\begin{abstract}
Newton's Laws which have explained the relationship between force and motion are milestones in the development of physics. In order to understand physics, learning force concepts and their relationship related to motion are necessary. For this reason, Science Teaching Curriculums have included subjects related to force and movement since primary education. When the literature is examined, it is seen that students tend to explain physical events with their daily experiences, and it is understood that student's perceptions about force look those of ancient philosophers' perceptions. This research, it is aimed to detect pupils' perceptions about force. For this purpose, phenomenology, one of the qualitative research designs, was used in the research. 113 primary school 4th-grade students studying in the fall semester of the 2019-2020 academic year (December / 2019) participated in the study. The data were collected with the help of students' drawings and explanations about the concept of force. Student's drawings were analyzed by content analysis. Themes, categories, and codes about the force were detected with this analysis. According to research results, students' perceptions about force are comprehensive. But there are some points that need to strengthen. Activities that teachers can apply in the classroom and distance education during the Covid-19 pandemic were expressed regarding these weak points.
\end{abstract}

Key Words: Science Education, Perception of Force, Physics Education, Qualitative Analysis, Phenomenology. 


\section{Giriş}

Evrenin temel prensipleri ile ilgilenen fizik, insanların evreni ve işleyişini anlamasını sağlayan temel bilimlerden biridir. Fizik, mekanik, termodinamik, elektrik ve manyetizma, 1şık ve optik, modern fizik olarak alt dallara ayrılmaktadır. Fiziğin temelini ise mekanik alt dalı altında incelenen Newton'un Temel Prensipleri oluşturur. Newton'un Temel Prensipleri, kuvvet ve kuvvetin hareket ile ilişkisini açılar. Bir başka ifade ile fiziğin anlaşılabilmesi için kuvvet kavramının doğru anlaşılması ön koşul özelliği sergilemektedir (Şimşek, Yurtcan ve Oktay, 2019). Bu nedenle fizik öğretim programlarında kuvvet ve etkilerinin öğretimine küçük yaş gruplarından itibaren yer verilmektedir (DfE, 2013; MEB, 2018; DfCELLS, 2008). Farklı ülkelerin (Türkiye, İngiltere ve Galler) öğretim programları incelendiğinde fizik ile ilk kez tanışan öğrencilerin kuvvetin hareket üzerindeki etkilerini (hızlanma, yavaşlama, dönme, sallanma, yön değiştirme) anlamalarının ve kuvvet çeşitlerini (yer çekimi kuvveti, manyetik kuvvet ve sürtünme kuvveti) bilmelerinin amaçlandığı anlaşılmaktadır. Başka bir deyişle bu öğretim programları ile fizik öğrenmeye yeni başlayan öğrencilerin kuvvet ile ilgili bilimsel bir algıya sahip olması istenmektedir.

Fizik öğretimi ile ilgili yapılan araştırmalar incelendiğinde öğrencilerin bu önemli kavram ile ilgili kavramsal anlama düzeyinin düşük olduğunu anlaşılmaktadır (Kuru ve Güneş, 2005). Öğrencilerin kuvvet ile ilgili algılarının çoğunlukla, kuvvet hareket ilişkisini net bir şekilde açıklayan Newton mekaniğine uygun olmadığı anlaşılmaktadır (Driver ve Easley, 1978; Finegold ve Gorsky, 1988).

Öğrencilerin kuvvet ile ilgili bilimsel olmayan görüşleri ve kuvvet kavramı ile ilgili algıları ilkçağ düşünürleri olan Aristotales'in ve Buridan'ın düşüncelerine ve kuvvet ile ilgili algılarına benzemektedir (Halloun ve Hestenes, 1985). Bu durumun nedeni öğrencilerin kuvvet kavramını ve etkilerini yorumlarken ilkçağ düşünürleri gibi kendi deneyimlerinden yararlanmalarıdır (Rakbamrung, Thepnuan ve Nujenjit, 2015; Kızılcık, 2013; Kurt ve Sarı, 2018; Yürümezoğlu, Ayaz ve Çökelez, 2009). Örneğin zihinlerinde kuvvet kavramı ile ilgili bilimsel olmayan düşünceleri ve algıları olan bir öğrenci ağırlığı bir kuvvet türü olarak değil bir kütle olarak ele almaktadır (Özsevgeç, Yurtbakan ve 
Uludüz, 2019). Öğrencilerin günlük tecrübelerinde kütlesi büyük olan cisimlerin ağırlığının büyük olması ile ilgili gözlemi bu düşüncelerini güçlendirmektedir.

Öğrencilerin kuvvet ile ilgili bilimsel olmayan düşünceleri Newton mekaniği ile açılanabilen birçok kinematik olayın yanlış yorumlanmasına neden olmaktadır. Bu durum aynı zamanda öğrencilerin fizik öğretiminde kuvvet kavramını doğru öğrenmelerinin önemini de göstermektedir. Araştırmacılar tarafından tespit edilen öğretimin farklı kademesindeki öğrencilerin bilimsel olmayan düşünceleri şu şekilde sıralanabilir;

1. Serbest düşme hareketi yapan bir cisme yerçekimi kuvveti yalnızca cisim yere doğru hareket ettiği sırada etki eder.

2. Çarpışan iki cisimden kütlesi büyük olan kütlesi küçük olana daha büyük bir kuvvet uygular.

3. Etki-tepki kuvvet çiftleri için çarpışan iki cisimden sürati fazla olan diğerine daha büyük bir kuvvet uygular.

4. Yerçekimi kuvveti insana etki eder. Sürtünme kuvveti ise hareket eden bir topa etki eder.

5. Hareket eden bir cisme mutlaka bir kuvvet etki eder.

6. Sabit hizla hareket eden bir cisme mutlaka sabit bir kuvvet etki eder (Narjaikaew, 2012).

7. Bir cisim atıldığı zaman, harekete neden olan kuvvet, cisme hareketi boyunca etki eder (Kuru ve Güneş, 2005).

8. Bir cismin ağırlığına kütle denir (Koray ve Tatar, 2003).

Alg1, nesnel dünyayı duyular yolu ile öznel bilince aktarmaktır. Bu sürece algılama, ortaya çıkan ürüne ise algı denilmektedir. Algılama sırasında $o$ anda yaşanan deneyimler geçmiş deneyimler ile harmanlanarak yeni bir ürüne ulaşılır (Şahin, 2020). Algılar zihindedir ve algıların ortaya çıkması için konuşmak, yazmak, şarkı söylemek veya eylemde bulunmak gibi davranışlar gerekir. Fizik öğretimi ile ilgili araştırmaların bir bölümü de öğrencilerin fizik ve fizik kavramları ile ilgili algılarını belirlemek üzerinedir. Fizik öğretiminde algıların araştırılma nedenlerinin başında öğrencilerin genellikle fizikten korkmasına bağlı olarak fizik öğrenmeye ve fizik konularına yönelik olumsuz tutum geliştirmeleridir (Doug, 2010). Öğrenciler fiziği zor, sıkıc1 ve karmaşık olarak tanımlamaktadır (Harman ve Çökelez, 2017). 
Alanyazın incelendiğinde öğrencilerin fizik ile ilgili algılarının yanı sıra fizik kavramları ile ilgili algılarını belirlemeye yönelik araştırmalara rastlanmıştır (Kızılcık, 2013; Kurt ve Sarı, 2018; Yürümezoğlu, Ayaz ve Çökelez, 2009).

Yukarıda ifade edildiği gibi öğrencilerin fizik kavramları ile ilgili sahip olduğu yanlış algılar, öğrencilerin bu kavramlar ile ilgili bilimsel olmayan düşüncelerin oluşmasına neden olmaktadır. Bu durum öğrencilerin fizik öğrenmesini güçleştirmektedir. Bu araştırmada fizik öğrenmek için ön koşul özelliği sergileyen ve yanlış öğrenildiğinde birçok kinematik olayın yanlış yorumlanmasına neden olan kuvvet kavramı ile ilgili 4. sınıf öğrencilerinin algılarını belirlemek amaçlanmıştır. Araştırmanın amacı doğrultusunda "Öğrencilerin kuvvet kavramı ile ilgili algıları nasıldır?" problemine yanıt aranmıştır.

\section{Yöntem}

\section{Araştırmanın Deseni}

$\mathrm{Bu}$ araştırmada öğrencilerin bir kavram ile ilgili algılarını belirlemek için uygun bir yöntem olması nedeni ile nitel araştırma desenlerinden olgu bilim (fenomenoloji) kullanılmıştır (Creswell, 2013). Olgu, birtakım olayların dayandığı sebep veya bu sebeplerin yol açtığı sonuçlara denir. Olgu bilim deseni farkında olduğumuz ancak derinlemesine ve ayrıntılı bir anlayışa sahip olmadığımız olguları incelemek için kullanılan bir desendir (Yıldırım ve Şimşek, 2008). Bu desen ile katılımcıların olaylara yüklediği anlamlar incelenir (Baş ve Akturan, 2013) ve bir olguya yüklenen ortak amaç belirlenmeye çalışılır (Karaçam ve Gürsel, 2017).

\section{Çalışma Grubu}

Araştırmanın örneklemi belirlenirken nitel araştırmalarda kullanılan ölçüt örnekleme yöntemi tercih edilmiştir. Olgu bilim araştırmalarında katılımcların belirlenmesinde en uygun yöntem ölçüt örneklemedir (Çilesiz, 2011). Bu örnekleme yönteminde ölçütler belirlenir ve bu ölçütleri karşılayanlardan bir örneklem oluşturulur. Bu araştırmada, örneklem belirlemek için ilk ölçüt şu şekilde tanımlanmıştır; öğrenciler 4 . 
sınıfta öğrenim görmelidir ve araştırmaya gönüllü olarak katılmalıdır. İkinci ölçüt olarak ise öğrenciler 3. ve 4. sınıf fen bilimleri öğretim programında yer alan "Kuvveti Tanıyalım" ve "Kuvvetin Etkileri" ünitelerini tamamlamış olmalıdır. Araştırmada 4. sınıf öğrencilerinin seçilme nedeni öğrencilerin kuvvet kavramı ile yeni karşılaşmış olmalarıdır. Çünkü bu araştırmada kuvvet kavramı ile yeni karşılaşan öğrencilerin zihinlerinde kuvvet kavramının nasıl oluştuğu araştırılmıştır.

Bu ölçütler göz önünde bulundurularak araştırmanın örneklemi 20192020 eğitim-öğretim yılında (Aralık/2019), Balıkesir ili merkezinde yer alan bir ilkokulun 4. sınıfında öğrenim gören 113 öğrenci olarak belirlenmiştir. Araştırmanın örneklemi seçilirken okulun sosyal, kültürel, ekonomik ve akademik başarı olarak ortalama düzeyde bir okul olmasına dikkat edilmiştir. Araştırmanın örneklemini oluşturan öğrencilerin \%55.75'i kız (f=63), \%44.25'i (f=50) erkek bireylerden oluşmaktadır. Yaş açısından bakıldığında ise araştırmaya katılan öğrencilerin \%81.42'si (f=92) 10, \%18.58' $\mathrm{i}(\mathrm{f}=21)$ ise 11 yaşındadır.

\section{Veri Toplama Aracı ve Verilerin Toplanması}

Öğrencilerin bir kavram ile ilgili algılarını belirlemenin yollarından biri öğrenci resimleridir (Yalçın ve Erginer, 2014; Babaoğlu ve Keleş, 2018). Çocukların çizimleri onların dış dünyayı algılama biçimlerini detaylı bir şekilde ortaya koyar.

Öğrencilerin algılarını belirlemek için resim çizimlerinin kullanımı son yıllarda artmaktadır (Bartoszeck ve Bartoszeck, 2017; Demirci, Yılmaz ve Şahin, 2016; Harrison ve Treagust, 1996; Karaçam ve Gürsel, 2017; Muştu ve Ucer, 2018; Turgut, Öztürk ve Eş, 2017).

$\mathrm{Bu}$ araştırmada öğrencilerin kuvvet kavramı ile ilgili algılarını belirlemek için öğrencilerden resim çizmeleri istenmiştir. Öğrenciler kuvvet kavramı ile fen bilimleri dersi öğretim programının ilkokul 3. sinif seviyesinde "Kuvveti Tanıyalım" ve 4. sinıf seviyesinde "Kuvvetin Etkileri" ünitelerinde karşılaşmaktadırlar. Olgu bilim araştırmalarında gözlem, sanat, şiir, müzik ve sanatın diğer biçimlerinden elde edilen veriler kullanılabilir (Creswell, 2007). Araştırmaya katılan öğrencilerin kuvvet kavramı ile ilgili algılarını belirlemek için öğrencilere "Kuvvet 
kavramını resim çizerek açıklayınız." sorusu yöneltilmiştir. Sorunun açıklama bölümünde ise öğrencilere kuvvet algılarını yansıtacak şekilde A4 boyutlarında bir kâğıda istedikleri sayıda farklı resim çizebilecekleri ve bu resmin/resimlerin altına yazacakları ifadeler ile resimlerini anlaşlır hale getirmelerinin önemi belirtilmiştir. Öğrencilere çizim yapmaları için bir ders saati zaman verilmiştir. Çizim süresince ders öğretmeni ve bir araştırmacı çizim ortamı olan sınıfta bulunmuştur. Ayrıca öğrencilere çizim sayısı ve renkli kalem kullanımı, boya türü, çizim tekniği gibi sınırlandırmalar getirilmemiştir. Öğrencilerin çizim yapmaları için fen bilimleri derslerinin olduğu saatler seçilerek farklı bir derste uygulama yapılmasının sebep olabileceği kaygıya engel olunmaya çalışılmıştır. Çalışmaya ilişkin tüm veriler 2019-2020 eğitim öğretim yılının güz döneminde (Aralık/2019) toplanmıştır.

\section{Verilerin Analizi}

Araştırma verileri nitel araştırma veri analiz yöntemlerinden biri olan içerik analizi ile yapılmıştır (Büyüköztürk vd., 2009). Öğrenci çizimleri önce kodlanmış ardından kodlar belirli kategoriler ve temalar altında toplanmıştır. Elde edilen bu kodların, kategorilerin ve temaların frekans dağılımları oluşturularak tablolar halinde sunulmuştur. Ayrıca kuvvet ile ilgili olarak belirlenen temalar ve kategoriler örnek öğrenci resimleri ile birlikte detaylı olarak incelenmiştir.

Verilerin analizinde ilk olarak iki araştırmacı tarafından tüm resimler incelenmiştir. Kuvvet kavramı ile ilişkili olmayan resimler veri setinden çıkarılmıştır. Veri setindeki diğer çizimler ise numaralandırılarak sıralanmıştır. Daha sonra iki araştırmacı ayrı ayrı resimleri kodlama işlemini gerçekleştirmiştir. Araştırmacılar arasında kodlama tutarlılığının hesaplanması için ortak kodlama yapılan çizim sayısı, ortak kodlanan ve farklı kodlanan çizim sayılarının toplamına bölünmüştür (Miles ve Huberman, 1994). Bu yöntem ile kodlayıcılar arasındaki tutarlılık \%97,8 olarak hesaplanmıştır. Bu sonuç araştırmacılar arasında kodlama tutarlılığı olduğunu göstermektedir. Araştırmacılar arasında görüş birliğine varılamayan çizimler için ise üçüncü bir uzmandan görüş alınarak çizime ait kod belirlenmiştir. Araştırmaya katılan öğrenciler istedikleri sayıda resim çizebildikleri için toplam çizim sayısı öğrenci 
sayısında fazladır. Bu sayede öğrencilerin kuvvet kavramına ilişkin algıları derinlemesine incelenmiştir. Ayrıca öğrencilerin çizimlerini yazılı olarak açıklamaları çizimlerin yorumlanmasını ve kodlanmasını kolaylaştırmıştır. Araştırmacılar kodları ortak anlamlarına göre kategori ve tema başlıkları altında toplamıştır.

\section{Bulgular}

Öğrencilerin gerçekleştirildiği çizimlerin araştırmacılar tarafından kodlanmasının ardından ortaya çıkan kodlar, kategoriler ve temalar Şekil 1'de verilmiştir.

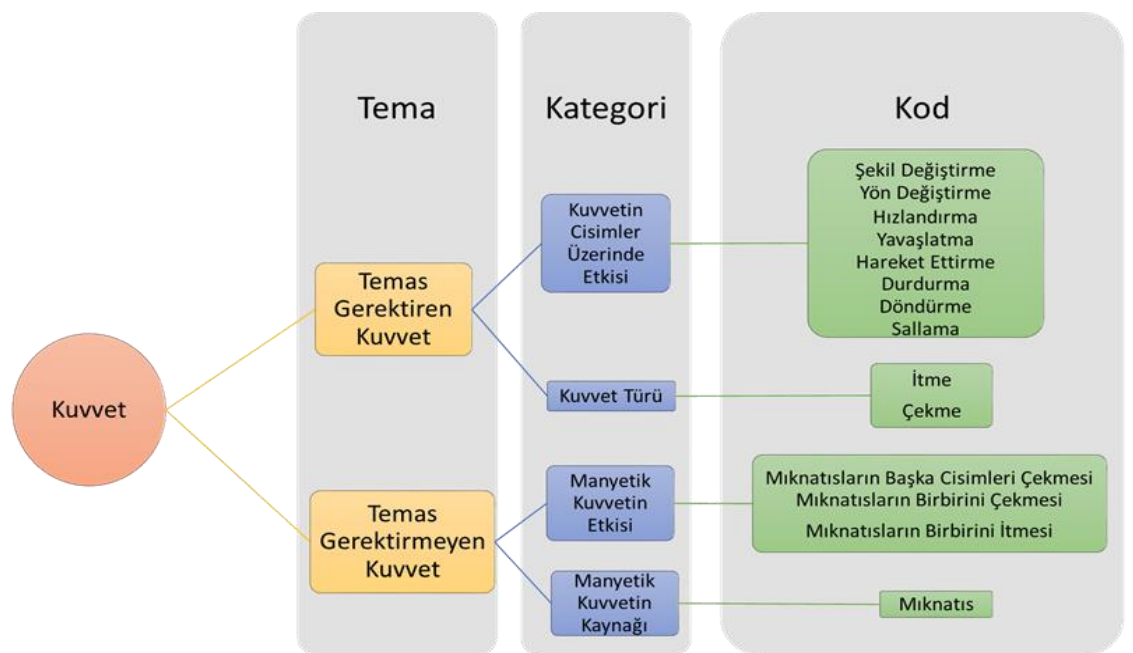

Şekil 1. Kuvvet Kavramı ile ilgili Kod, Kategori ve Temalar

Verilerin analizi sonucunda 14 kod tespit edilmiştir. Şekil değiştirme, yön değiştirme, hızlanma, yavaşlama, hareket ettirme, durdurma, döndürme, sallanma durumlarının tümü kuvvetin cisimlere etki etmesi sonucunda oluşur. Bu nedenle bu kodlar kuvvetin cisimler üzerinde etkisi kategorisi altında toplanmıştır. İtme ve çekme, Milli Eğitim Bakanlığ1 Fen Bilimleri Öğretim Programında (2018) birer kuvvet türü olarak ifade edildiği için kuvvet türü kategorisi altında toplanmıştır. Mıknatısların başka cisimleri çekmesi, mıknatısların birbirini çekmesi ve miknatısların birbirini itmesi manyetik kuvvetin etkileridir. Bu nedenle 
belirlenen bu kodlar bu kategori altında toplanmıştır. Son olarak mıknatıs kodu ise manyetik kuvvetin kaynağı olduğundan bu kategori altında toplanmıştır.

Kuvvetin cisimler üzerine etkisi ile kuvvet türü kategorilerinin ortak özelliği temas gerektiren kuvvetler ile ilgili olmalarıdır. Manyetik kuvvetin etkisi ile manyetik kuvvetin kaynağının ortak özelliği ise temas gerektirmeyen kuvvetler ile ilgili olmalarıdır. Bu nedenle de bu temalar altında toplanmıştır.

Tablo 1'de bu kod, kategori ve temaların frekans dağılımları yer almaktadır.

Tablo 1. Kuvvet ile ilgili kod, kategori ve tema frekanslarn

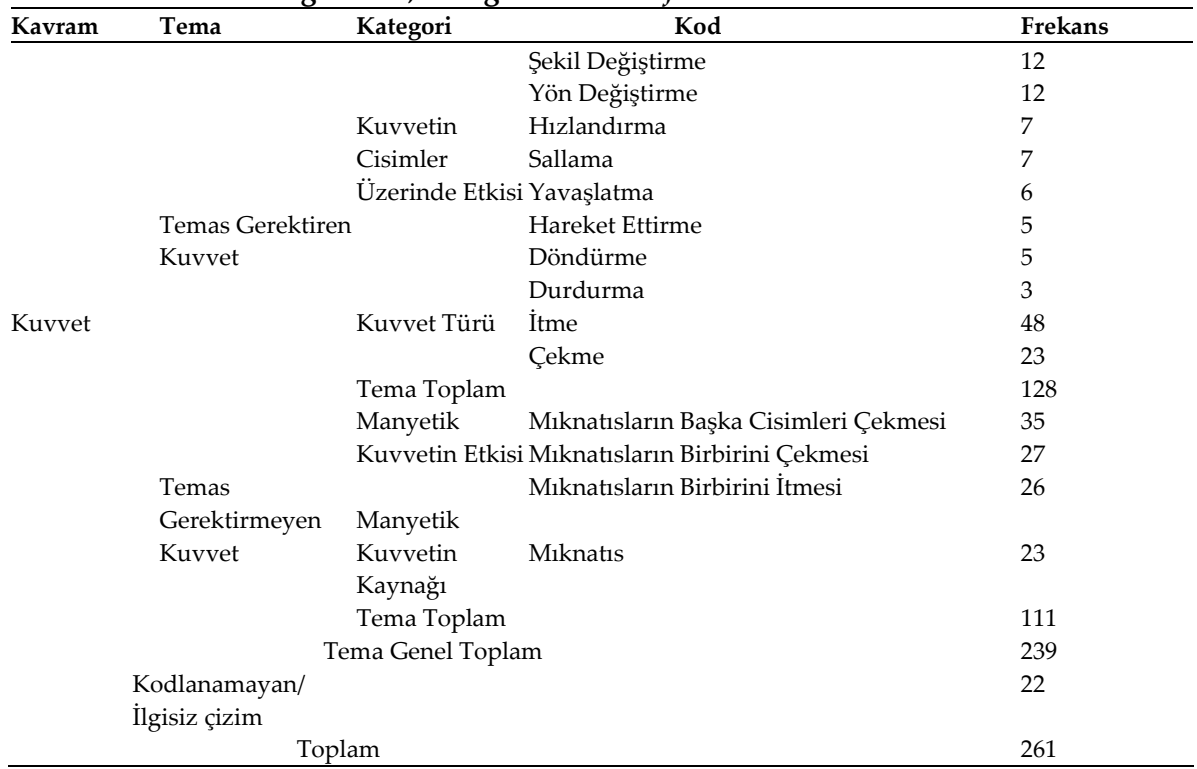

Araştırmada toplam 261 çizim incelenmiştir. Bu çizimlerden 22'si kodlanamamıştır. Geriye kalan 239 çizim belirli bir kod altında toplanmıştır. Araştırmada öğrenci çizimlerinin en fazla toplandığı kod "itme", kategori "manyetik kuvvetin etkisi", tema ise "temas gerektiren kuvvet"tir. Ayrıca öğrenci çizimlerinin "mıknatısın başka cisimleri çekmesi", "mıknatısın birbirini çekmesi", "mıknatısın birbirini itmesi", "mıknatıs", "çekme", "şekil değiştirme" ve "yön değiştirme" kodlarında, 
"kuvvet türü" kategorisinde ve "temas gerektirmeyen kuvvet" temasında da sıklıkla toplandığı anlaşılmaktadır. Öğrencilerin en az toplandığı kod "durdurma", kategori "manyetik kuvvetin kaynağı", tema ise "temas gerektirmeyen kuvvettir".

Bir sonraki bölümde her bir tema ve kategori ile ilgili öğrenci çizimleri detaylı olarak incelenmiştir.

\section{Temas Gerektiren Kuvvet Teması - Kuvvetin Cisimler Üzerindeki Etkisi Kategorisi Kodları ile İlgili Örnek Çizimler}

"Temas gerektiren kuvvet" teması, "kuvvetin cisimler üzerindeki etkisi" kategorisi altında yer alan "şekil değiştirme, yön değiştirme, hızlandırma, yavaşlatma, hareket ettirme, durdurma, döndürme, sallama" kodlarına ilişkin örnek çizimler ve açılamalar sırası ile verilmiştir. İlk olarak Şekil 2'de "şekil değiştirme" ve "yön değiştirme" koduna ilişkin örnek çizimler bulunmaktadır.

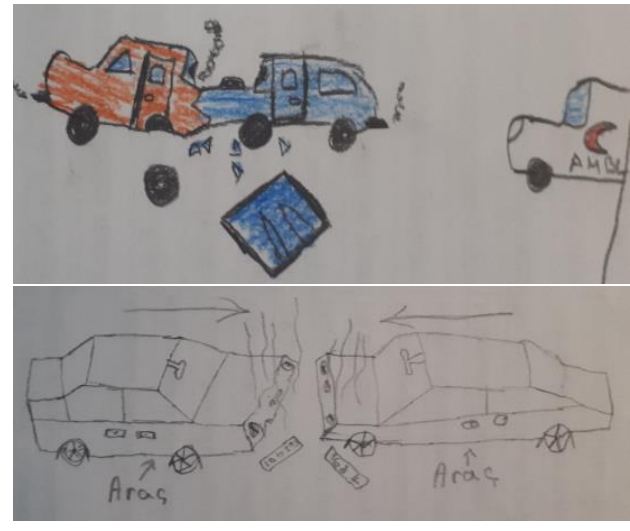

(a)

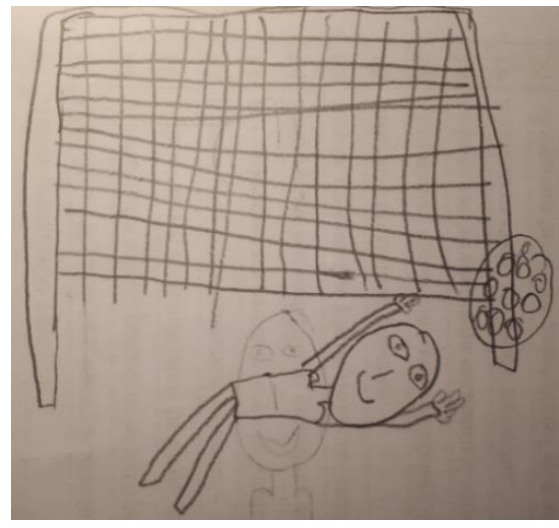

(b)

Şekil 2. a. Şekil Değiştirme (Çizim 17 ve Çizim 86) b. Yön Değiştirme (Çizim 68) Koduna İlişkin Örnek Çizimler

Öğrencilerin şekil değiştirme ile ilgili gerçekleştirmiş olduğu çizimler incelendiğinde genellikle araç kazalarını öne çıkardıkları görülmektedir. 17 numaralı çizimi gerçekleştiren öğrenci "Kazalarda arabalar çarpışınca çok fazla kuvvet uygulanır ve arabaların önü yamulur" ifadesini 
kullanmıştır. Ayrıca öğrencilerden bazıları şekil değiştirme ile ilgili yapmış oldukları çizimlerde süngerin ve oyun hamurunun "kuvvet uygulanarak sıkılması sonucunda şeklinin değiştirilmesi" durumunu resmetmişlerdir. Kimi öğrenciler de bir kalemin kırılması durumunu çizimlerinde ve açıklamalarında belirtmişlerdir. Yön değiştirme ile ilgili öğrencilerin gerçekleştirdiği çizimler incelendiğinde ise genellikle futbola ilişkin çizimler ağırlıklıdır. Örneğin çizim 68 için öğrenci "Kaleye doğru gelen topa kaleci kuvvet uygulayarak topun yönünü değiştirir" açıklamasını yapmıştır. Benzer biçimde çarpışan arabaları çizen bir öğrencide "Çarpışan arabalar birbiriyle çarpışınca kuvvet uygularlar yönler değişir" ifadesini açıklama kısmında kullanmıştır. İki öğrenci de tenis oynayan sporcuları çizmişlerdir. Bir tanesi çizmiş olduğu resmi açıklamak için "Raket ile topa vurarak topun yönünü değiştirebiliriz" ifadesini kullanmıştır. "Hızlandırma" ve "yavaşlatma" koduna ilişkin örnek çizimler Şekil 3'te verilmiştir.

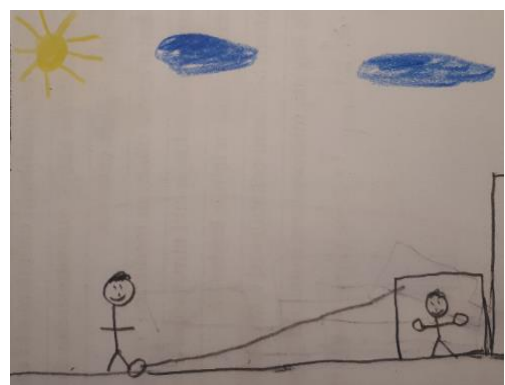

(a)

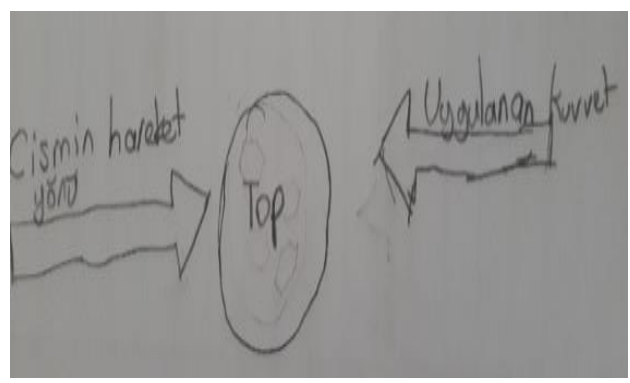

(b)

Şekil 3. a. Hızlandırma (Çizim 73) b. Yavaşlatma (Çizim 102) Koduna İlişkin Örnek Çizimler

Öğrencilerin hızlandırma ve yavaşlatma kodu altında toplanan çizimleri incelendiğinde genellikle futbol/top ve oyuncak araba ile ilgili çizimler yaptıkları görülmektedir. 73 numaralı çizimi gerçekleştiren öğrenci "Futbol oynarken giden topa vurduğumuzda hızlanıp gol olur" ifadesini kullanmıştır. Bunun yanı sıra bazı öğrenciler oyuncak arabalar ile oynayan ve onları elleri ile hızlandıran çocukları resmetmişlerdir. Yavaşlatma kodu ile gerçekleştirilen çizim 102'de bir top üzerine etki eden kuvvetler çizilmiştir. Öğrenci çizim 102 için “Uygulanan kuvvet 
cismin hareket yönüne ters. Onun için top yavaşlar" açıklamasını yapmiştır.

"Hareket ettirme" ve "durdurma" koduna ilişkin örnek çizimler Şekil 4 'te verilmiştir.

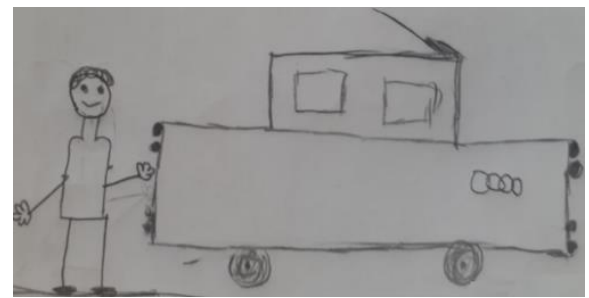

(a)

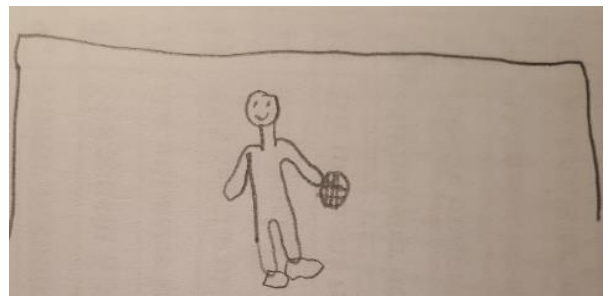

(b)

Şekil 4. a. Hareket Ettirme (Çizim 186) b. Durdurma (Çizim 39) Koduna İlişkin Örnek Çizimler

Öğrencilerin hareket ettirme kodu altında toplanan çizimleri incelendiğinde genellikle ( 3 çizim) arabaların hareket ettirilmesi ve durdurulması ile ilgili çizimler yaptıkları görülmektedir. 186 numaralı çizimi gerçekleştiren öğrenci "Duran arabaya kuvvet uygulayan adam arabayı hareket ettiriyor" ifadesini kullanmıştır. Bunun yanı sıra diğer öğrenciler futbol topunun ve oyuncak arabanın hareket ettirildiği durumları resmetmişlerdir. Durdurma kodu ile kodlanan çizimlerde araba ve top ile ilgili durumlar bulunmaktadır. Örneğin 39 numaralı çizimi gerçekleştiren öğrenci açılama kısmında "Kaleci kuvvet uygulayarak topu durdurur" açıklamasını yapmıştır.

"Döndürme" ve "sallama" koduna ilişkin örnek çizimler Şekil 5'te verilmiştir. 


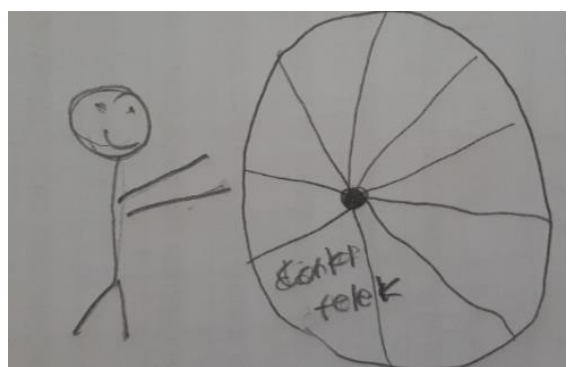

(a)

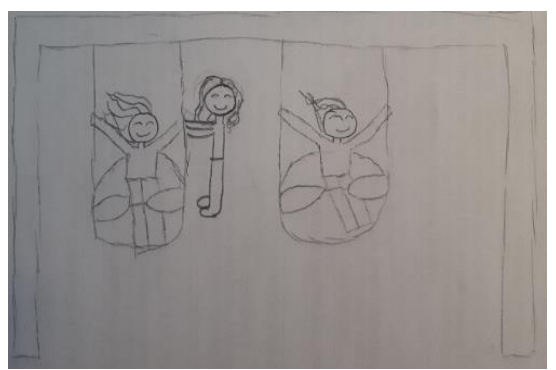

(b)

Şekil 5. a. Döndürme (Çizim 145) b. Sallama (Çizim 96) Koduna İlişkin Örnek Çizimler

Öğrencilerin döndürme ile ilgili çizimlerde genellikle çarkıfelek isimli yarışmada bulunan ve çevrilen çarkı çizdikleri görülmüştür. Bunun yanı sıra dönme dolabın dönmesi de çizimler arasında yer almaktadır. Örneğin 145 nolu çizimi yapan öğrenci açıklama kısmında "Adam çarkıfelek yarışmasında çarkı döndürüyor" ifadesini kullanmıştır. Sallama kodu ile kodlanan çizimler detaylı incelendiğinde ise tamamının salıncakta birbirini sallayan kişileri içerdiği görülmüştür. Bunun dışında kuvvetin sallama etkisini betimleyen farklı bir çizime rastlanmamıştır. Çizim 96'yı çizen bir öğrenci açılama kısmında “Ablası kuvvet uygulayıp kardeşlerini sallıyor" ifadesini kullanmıştır.

\section{Temas Gerektiren Kuvvet Teması - Kuvvet Türü Kategorisi Kodları ile İlgili Örnek Çizimler}

Çalışmanın bu bölümünde "temas gerektiren kuvvet" teması, "kuvvet türü" kategorisi altında yer alan kodlara ilişkin örnek çizimler ve açıklamalar verilmiştir. Bu kategori altında "itme" ve "çekme" kodları bulunmaktadır. İtme koduna ilişkin 48 öğrenci çizim yaparken çekme kodu ile kodlanan 23 çizim gerçekleştirilmiştir. Şekil 6'da itme ile ilgili öğrencilerin gerçekleştirdiği çizimlere örnekler verilmiştir. 


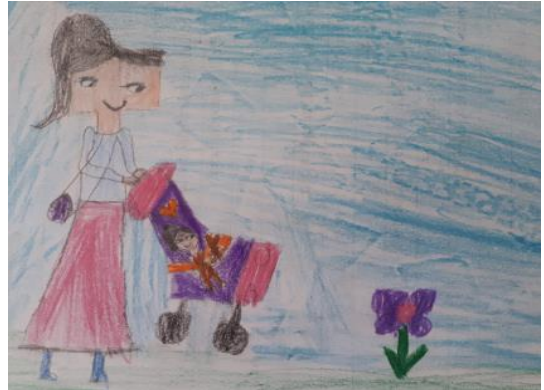

(a)

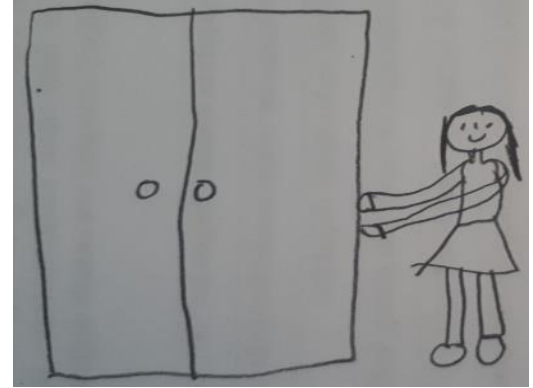

(b)

Şekil 6. İtme ile İlgili çizimler a. Bebek Arabası (Çizim 156) b. Dolap (çizim 72)

İtme ile ilgili çizimler incelendiğinde genellikle ev içerisinde yer alan pencere, dolap, sehpa, masa, sandalye gibi nesnelere uygulanan kuvvetin resmedildiği ve açıklama kısmında itme ile ilişkili açıklamalar yapıldığı görülmüştür. Bunun yanı sıra öğrenciler itme olarak açıkladıkları durumları sıklıkla bozulan/yakıtı biten arabaların, market arabalarının, bebek arabalarının ve oyuncaklarının itildiği durumlar ile resmetmişlerdir. Örneğin çizim 156 için "Annesi bebeğini bebek arabasına koymuş ve itiyor", çizim 72 için ise "Kız odasındaki dolabını itiyor" açıklamaları yapılmıştır.

Çekme kodu ile kodlanan çizimlerin de itme kodu altında toplanan çizimlere benzer şekilde ağırlıklı olarak ev içinde bulunan eşyalar ile ilgili olduğu belirlenmiştir. Şekil 7'de çekme ile ilgili çizim örnekleri verilmiştir.

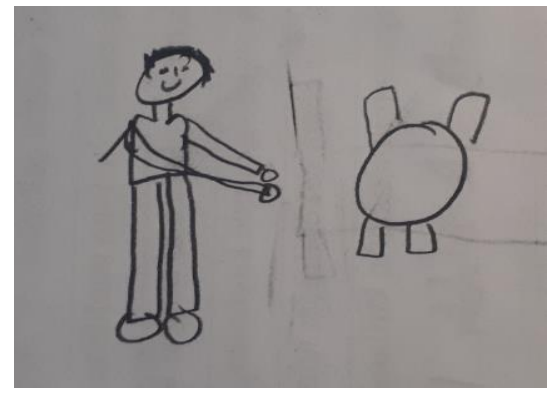

(a)

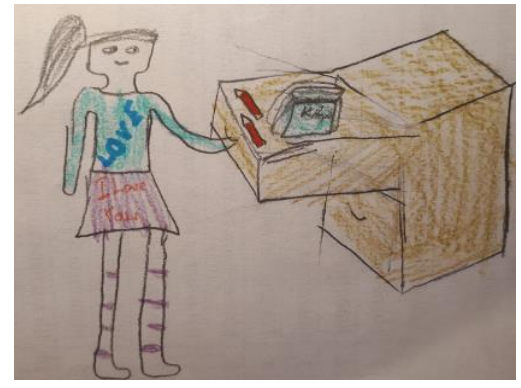

(b)

Şekil 7. Çekme ile İlgili Çizimler a. Sehpa (Çizim 63) b. Çekmece (Çizim 88) 
Çekme ile ilgili çizim yapan öğrencilerin çekmece, buzdolabı kapağı, pencere gibi ev içindeki eşyaların dışında halat çekme oyunu, ipe bağlı oyuncak arabanın çekilmesi gibi oyunlar ile ilişkilendirdikleri de görülmüştür. Ayrıca öğrenciler akıllı tahtanın açılması gibi sınıf ile ilişkilendirilen durumları da resmetmişlerdir. Çekme kodu ile kodlanan çizimlere yapılan açıklamalar ise "Sehpanın yerini değiştirmek için abim sehpayı çekiyor" (çizim 63) ve "Çekmeceyi çekerek açtım ve içinden defterimle kalemlerimi aldım" (çizim 88) biçiminde olmuştur.

\section{Temas Gerektirmeyen Kuvvet Teması - Manyetik Kuvvetin Etkisi Kategorisi Kodları ile İlgili Örnek Çizimler}

Çalışmanın bu bölümünde "temas gerektirmeyen kuvvet" alt teması, "manyetik kuvvetin etkisi" kategorisi altında yer alan kodlara ilişkin örnek çizimler ve açıklamalara yer verilmiştir. Şekil 8'de "mıknatısların başka cisimleri çekmesi" kodu ile ilgili öğrencilerin gerçekleştirdiği çizimlere örnekler verilmiştir.

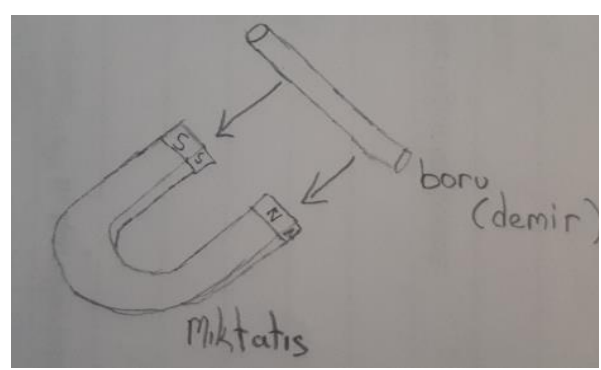

(a)

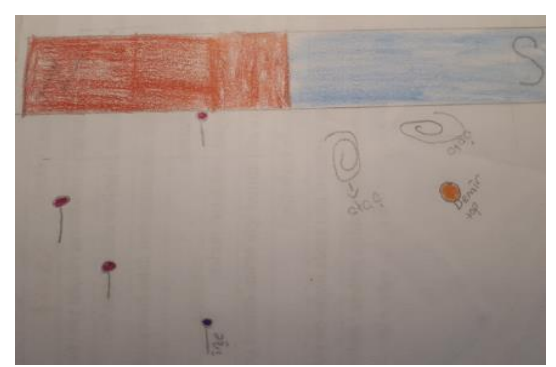

(b)

Şekil 8. Mıknatısların Başka Cisimleri Çekmesi a. Demir Boru (Çizim 93) b. Ataç, İğne, Demir Top (Çizim 153)

Öğrencilerin "mıknatısların başka cisimleri çekmesi" kodu ile kodlanan çizimleri incelendiğinde $U$ mıknatıs ve çubuk mıknatısın her ikisinin de kullanıldığı görülmüştür. Resimler detaylı olarak incelendiğinde ise çubuk mıknatısın bir cismi çektiği çizim sayısının (8 çizim), U mıknatısa göre oldukça az olduğu (27 çizim) görülmüştür. Çekilen cisimler arasında çivi, metal para, toplu iğne, metal bilye, ataş, demir, anahtar, oyuncak araba, metal kaşık ve biçak ile makas 
bulunmaktadır. Gerçekleştirilen iki çizimde ise öğrenciler açıklama kısmında mıknatıslar tarafından "demir, nikel ve kobalt"ın çekildiğini belirtmişlerdir. Ayrıca öğrencilerin bu kod ile ilgili olan tüm çizimlerinde çubuk ve U mıknatısların iki kutbunun da belirtildiği görülmüştür. Açılama kısımları incelendiğinde ise çizim 93'te "Mıknatıs demir bir boruyu çekip kuvvet uyguluyor", çizim 153'te ise "Mıknatıs ile iğne, ataç, demir topu çekebiliriz. Mıknatıs çektiği için kuvvet uygular" ifadeleri yer almaktadır.

Şekil 9'da "mıknatısların birbirini çekmesi" kodu ile ilgili öğrencilerin gerçekleştirdiği çizimlere örnekler verilmiştir.

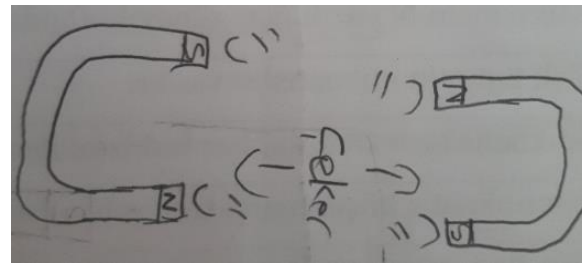

(a)

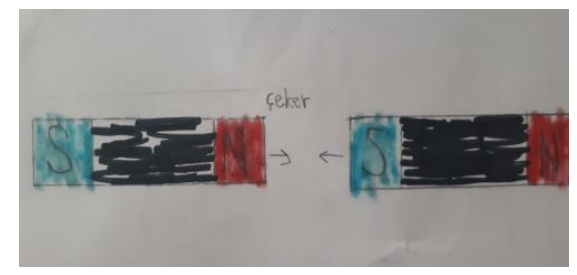

(b)

Şekil 9. Miknatısların Birbirini Çekmesi a. U Miknatıs (çizim 59) b. Çubuk Miknatıs (Çizim 128)

Öğrenciler "mıknatısların birbirini çekmesi" durumunu resmederken U mıknatısları ve çubuk mıknatısları kullanmışlardır. Bu çizimlerden sadece bir tanesinde çubuk mıknatıs ile U mıknatısın birbirini çekmesi durumu vardır. Diğer tüm çizimlerde ya iki U mıknatıs (14 çizim) ya da iki çubuk mıknatıs (12 çizim) birbirini çekmektedir. Açıklama kısmında is çizim 59 için" Zıt kutuplar birbirini çeker", çizim 128 için ise "Zıt kutuplu mıknatıslar birbirini çekerek kuvvet uygular" ifadesi yer almaktadır.

"Mıknatısların birbirini itmesi" kodu altında toplanan çizimlere örnekler ise Şekil 10'da verilmiştir. 


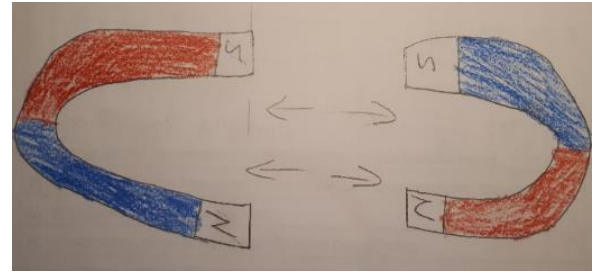

(a)

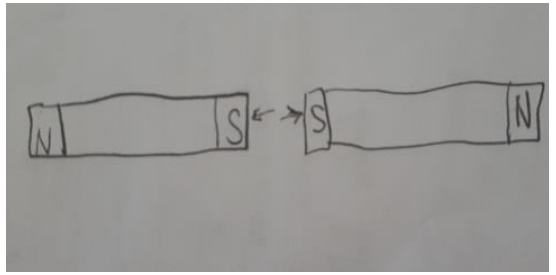

(b)

Şekil 10. Mıknatısların Birbirini İtmesi a. U mıknatıs (Çizim 51) b. Çubuk Miknatıs (Çizim 27)

"Mıknatısların birbirini çekmesi" kodu ile ilişkilendirilen çizimlere benzer şekilde "mıknatısların birbirini itmesi" ile ilgili kodun atında toplanan çizimlerde U mıknatıs (14 çizim) ve çubuk mıknatısların (12 çizim) her ikisi de kullanılmıştır. Fakat bir önceki durumdan (çekme) farklı olarak çubuk ve U miknatısın birlikte olduğu bir çizim gerçekleştirilmemiştir. Ayrıca iki öğrenci U mıknatısların birbirini çektiği durumu oklar ile ifade etmiş fakat mıknatısların kutuplarını belirtmemiştir. Açıklamalar incelendiğinde çizim 51 için "Aynı kutupları birleştiremeyiz, birbirini iter", çizim 27 için "Aynı kutuplar birbirini iter" ifadeleri kullanılmıştır.

\section{Temas Gerektirmeyen Kuvvet Teması - Manyetik Kuvvetin Kaynağı Kategorisi Kodları İlgili Örnek Çizimler}

Çalışmaya katılan 26 öğrenci resimlerinde sadece mıknatısın olduğu çizimleri gerçekleştirmiştir. Öğrenciler kuvvet kavramını mıknatıs ile açıklamaya çalışmışlardır. "Mıknatıs" kodu ile kodlanan çizimlere ilişkin örnekler Şekil 11'de verilmiştir.

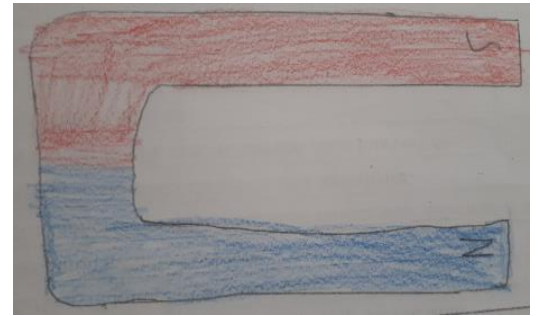

(a)

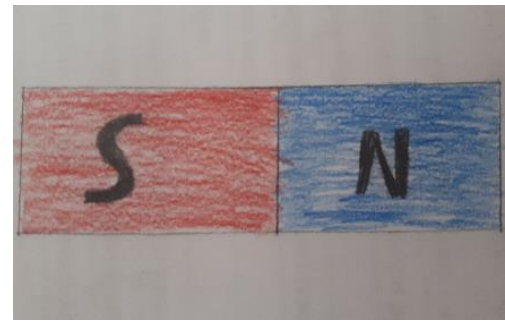

(b) 


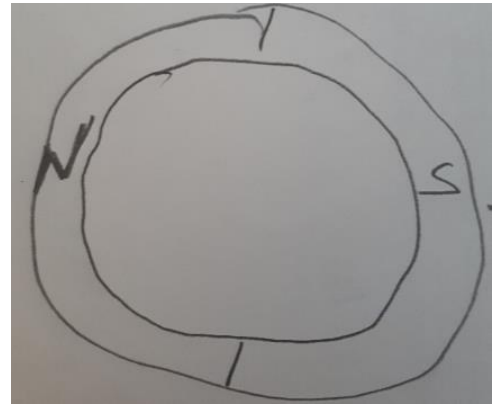

(c)

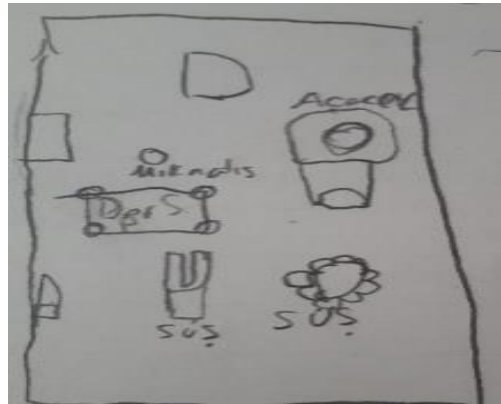

(d)

Şekil 11. a. U Miknatıs (Çizim 13) b. Çubuk Miknatıs (Çizim 210) c. Halka Mıknatıs (Çizim 22) d. Magnet (Buzdolabı Süsü) (Çizim 5)

Öğrencilerin 9 tanesinin U miknatıs, 5 tanesinin çubuk miknatıs 3 tanesinin halka miknatıs, 1 tanesinin disk (yuvarlak) miknatıs ve 6 tanesinin de magnet (buzdolabı süsü) çizmiştir.

\section{Tartışma ve Sonuç}

$\mathrm{Bu}$ araştırmada 4. sınıf öğrencilerinin kuvvet kavramı ile ilgili algılarının belirlenmesi amaçlanmıştır. Öğrencilerin zihinlerinde kuvvetin etki ettiği cisim ile temas etmesi yönü ağır basmaktadır. Bununla birlikte öğrencilerin kuvvetin cisimlere temas etmeden de etki edebileceği bilgisine sahip olduğu anlaşılmıştır. Öğrencilerin bu bilgiyi edinmesinde 4. sınıf Fen Bilimleri Dersi Öğretim Programında mıknatıslara yer verilmesinin etkisi olduğu anlaşılmaktadır.

Araştırmada öğrencilerin kuvvetin cisimleri itmesi özelliğini sıklıkla ifade ettikleri fakat kuvvetin cisimleri durdurma özelliğini aynı sıklıkla ifade etmedikleri anlaşılmıştır. Öğrencilerin zihinlerinde kuvvet ile ilgili kapsayıcı algılarının oluşabilmesi için kuvvetin cisimleri durdurma özelliğini vurgulayan örnek ve etkinliklere yer verilmelidir. Araştırmaya katılan öğrencilerin Fen Bilimleri ders kitabı (Yaman, Akan, Doğan ve Sarı, 2019) incelendiğinde "Kuvvetin Etkileri" ünitesinde yer alan örneklerde ve etkinliklerde kuvvetin cisimleri hareket ettirme özelliğine sıklıkla yer verildiği fakat durdurma özelliğine aynı sıklıkla yer verilmediği tespit edilmiştir. Kitapta hareket ettirme kelimesi 15 kez geçmektedir fakat durdurma kelimesi dört kez geçmektedir. 
Öğrenci çizimlerinde yer alan örneklerin ders kitaplarında yer alan örnekler ile paralellik göstermesi dikkat çekicidir. Ders kitaplarında oyuncak/gerçek araba, sünger, oyun hamuru ve tenis ile ilgili örneklere rastlanmıştır. Benzer örneklere öğrenci çizimlerinde de rastlanmıştır. Bu sonuç ders kitabında verilen örneklerin öğrencilerin kuvvet algılarının oluşmasında önemli bir yeri olduğunu göstermektedir.

Ders kitaplarında araba çarpışmaları, kalem kırılması, futbol oyunu, çarkıfelek ve dönme dolap ile ilgili örneklere ve etkinliklere rastlanmamıştır. Öğrencilerin çizimlerinde ise bu örneklere rastlanmıştır. $\mathrm{Bu}$ çizimlerde öğretmenlerin derste verdiği örneklerin ve öğrencilerin günlük hayatta ilgisini çeken durumların etkisi olduğu düşünülmüştür. $\mathrm{Bu}$ durumdan yola çıkarak öğretmenlere çeşitli etkinlikler önerilebilir. Öğrencilerin kuvvet algisında sporun özelliklede futbolun önemi olduğu anlaşılmaktadır. Popüler bir spor olması nedeni ile öğrenciler kuvvet ile futbolu ilişkilendirmiştir. Bu nedenle öğretim etkinliği olarak öğretmenlere futbol, basketbol gibi öğrencilerin ilgisini çeken sporlarda topların hareketi, bir haltercinin halteri kaldırması gibi örneklere yer verilmesi önerilmektedir. Ayrıca, öğrencilere cansız mankenlerle gerçekleştirilen çarpışma testleri izletilebilir. Bu etkinlik ayrıca emniyet kemerinin önemi konusunda farkındalık oluşturmada da etkili olabilir. Tüm bunlara ek olarak, öğretimde kuvvetle ilgili yaşam temelli ve bağlam temelli drama etkinliklerine yer verilebilir (Yıldırım ve Gültekin, 2017; Bülbül ve Aktaş, 2013).

Araştırmada temas gerektirmeyen kuvvet teması ve manyetik kuvvetin etkisi kategorisi ile ilgili öğrenci çizimleri incelendiğinde, öğrencilerin mıknatısın başka cisimleri çekmesi ile ilgili çizimlerde özellikle U mıknatısı kullanmaları ve miknatısların kutuplarını göstermeyi unutmamaları dikkat çekicidir. Kuvvetin cisimler ile temas etmeden de etki edebileceğinin anlaşılması açısından öğretim programında 4. sınıfta "Kuvvetin Etkileri" ünitesi içinde "Miknatısların Uyguladığı Kuvvet" bölümüne yer verilmesinin yararlı olduğu söylenebilir. Bu konunun öğretimi için etkinlik olarak çubuk ve U mıknatıs ile sınıf ortamında farklı cisimleri çekip çekmeme durumlarının incelenmesi önerilebilir. Öğrencilerin mıknatısların birbirini itme ve çekme durumu ile ilgili çizimleri incelendiğinde öğrencilerin çubukçubuk veya $U$ mıknatıs-U mıknatıs çekme-itme durumlarını çizdiği 
gözlenmiştir. Bu çizimlerden öğrencilerin mıknatıslar arasındaki itme ve çekme durumunu özdeş mıknatıslarda olan bir durum olarak algıladıkları anlaşılmaktadır. $\mathrm{Bu}$ nedenle öğrencilere bu konunun öğretimi için çubuk ve U mıknatısların birbirini itme-çekme durumları ile ilgili uygulamalar yaptırılabilir. Araştırmada öğretim programında tanımlanmış olmasına rağmen mıknatısların günlük hayattaki kullanım alanları ile ilgili öğrenci çizimlerine rastlanmamıştır. Öğrencilerin kuvvet ile ilgili geniş bir algılarının oluşabilmesi için mıknatısların günlük hayattaki kullanımı ile ilgili örneklerin üzerinde durulması önerilmektedir. Örneğin iki yuvarlak mıknatıs, bir kalem pil ve bir de yay kullanılarak sınıf içinde bir maglev treni modeli yapılabilir. Ardından bu tren ile ilgili bir video izletilebilir (Criado and Alamo, 2016).

Araştırma sonuçları bir bütün olarak incelendiğinde öğrencilerin kuvvet ile ilgili algılarının kapsamlı olduğu söylenebilir. Bu durum 4. sınıf öğretim programının, ders kitaplarının ve sınıfta yapılan öğretimin öğrencilerde kuvvet algısı oluşturmada etkili olduğu şeklinde yorumlanmıştır. Buna rağmen öğrencilerin kuvvet algisında güçlendirilmesi gereken noktaların olduğu tespit edilmiştir. Tespit edilen bu noktalar ile ilgili önerilen örnekler ve etkinlikler öğretmenler tarafından hem sınıf ortamında hem de Covid-19 pandemi sürecinde uzaktan eğitim etkinlikleri olarak kullanılabilir. 


\title{
EXTENDED ABSTRACT
}

\section{Determination of Primary School Students' Perceptions about Force with the Help of Drawing}

\author{
Mustafa Çoramık- Erdoğan Özdemir \\ Balkesir University-Cumhuriyet University
}

Physics, which is interested in the basic principles of the universe, is a fundamental science that enables people to understand the universe. The basic principles of Newton laid the foundation of physics. These principles explain the force and its relationship with motion. It is known that understanding the basic principles of Newton is a precondition for understanding physics. Therefore, the topic of force and its effects is included in primary schools' education curriculum. When the curriculum of different countries are examined, it is understood that the students who are introduced to the physics course for the first time are aimed to have a scientific perception about force. On the other hand, it is detected that the conceptual understanding of students is low about this important concept. In addition, this lack of conceptual understanding about force causes a lot of unscientific thoughts about the other physics concepts for students. This case makes it difficult for students' understanding physics. In this research, it is aimed to determine the primary students' perceptions about the force which is a very important concept for teaching physics. For the purpose of the research, the problem statement is as follows; "How are the students' perceptions about force concept?"

Phenomenology was used as a research method in this research. The research sample was detected with the criterion sampling method which is preferred in quantitative researches. The research sample has composed of 113 th degree primary school students. 55.75 ( $\mathrm{f}=63$ ) percent of these participants are girls and $44.25(\mathrm{f}=50)$ percent of these participants are boys. $81.42(\mathrm{f}=92)$ percent of these students are 10 and $18.58(\mathrm{f}=21)$ percent of them are 11 years old. The following question has been asked participants: "Explain the concept of force with a drawing". Data were analysed with content analysis. 261 drawings of students were 
examined and 239 of these were coded. After that, these codes were grouped into certain categories and themes. The coding consistency between the two researchers was calculated as $97.8 \%$. Percentage of these codes, categories, and themes obtained with content analysis were presented with tables in this research. Additionally, these themes and categories about force were explained in detail with sample student drawings.

As a result of the analysis, 14 codes, four categories (the effect of force on objects, the type of force, the effect of magnetic force and the source of magnetic force), and two themes (the contact force and the non-contact force) were determined. Distribution of the codes to themes as follows; The codes of "deformation", "change of direction", "acceleration", "deceleration", "moving", "stopping", "rotation", and "swinging" were grouped under the category of "the effect of force on objects". Codes of "push" and "pull" were grouped under the category of "the type of force". Codes of "attracting the different objects with magnets", "attracting magnets to each other" and "magnets repel to each other" were grouped under "the effect of magnetic force". The code of "magnet" was also grouped under "the source of magnetic force". The "push", "the effect of magnetic force", and "the contact force" are the most gathered code, category, and theme of the students' drawings in this research. Other codes and categories which students' drawings are collected frequently are as follows: "attracting magnets to each other", "magnets repel to each other", "magnet", "pull", "deformation" and "change of direction" (codes) and "the type of force" (category). On the other hand, code, category, and theme in which student's drawings are collected rarely are as follows: stopping (code), the source of magnetic force (category), and the non-contact force (category).

The necessity of contact for force is the dominant perception of the students about force. On the other hand, it is also detected that students have got the knowledge of force can affect objects without contact. In the research, pushing the object was detected as one of the properties of the force frequently. But, stopping the object was detected as one of the properties of the force rarely. Samples that emphasizing the stopping feature of force should be included to form inclusive perceptions about force in students' minds. According to students' drawings, football is 
important for the perception of force. For this reason, it is recommended teachers to give examples of sports to the students as a teaching activity in the lessons. For example, throwing the ball, lifting the barbell, etc. In addition, students can be watched crash tests with inanimate dummies. In addition to all these, life-based and context-based drama activities related to power can be included in teaching.

According to students' drawings, students think that only identical magnets can push and pull each other. Pulling and pushing activities with a bar magnet and a horseshoe magnet can be performed to prevent this perception. Additionally, giving samples in the lessons about using magnets in daily life can affect positively students' wide perception of magnetic force (e.g. maglev train).

\section{Kaynakça / References}

Babaoğlu, G. ve Keleş, Ö. (2018). 6. sınıf öğrencilerinin "yıldız" “gezegen” “ay, dünya ve güneş" kavramlarına yönelik algılarının belirlenmesi. Karaelmas Ĕ̆itim Bilimleri Dergisi, 6, 127-145.

Bartoszeck, A. B. ve Bartoszeck, F. K. (2017). Brazilian primary and secondary school pupils' perception of science and scientists. European Journal of Educational Research, 6(1), 29-40. doi: 10.12973/eu-jer.6.1.29.

Baş, T. ve Akturan, U. (2013). Nitel araştırma yö̈temleri. Seçkin Yayıncllı: Ankara.

Bülbül, M.Ş. ve Aktaş, G. (2013). Fizik dersleri için bağlam temelli drama uygulamaları. Eğitim ve Öğretim Araştırmaları Dergisi, 2(1). 381-389.

Büyüköztürk, Ş., Kılıç-Çakmak, E., Akgün, Ö. E., Karadeniz, Ş. ve Demirel, F. (2009). Bilimsel araştırma yöntemleri. Ankara: Pegem A Yayıncllı.

Creswell, J. W. (2007). Qualitative inquiry and research design: Choosing among five approaches ( 2 nd ed.). Thousand Oaks, CA: Sage.

Creswell, J. W. (2013). Research design: Qualitative, quantitative, and mixed methods approaches. ThousandOaks, CA: Sage.

Criado, C. ve Alamo (2016). World's simplest electric train. American Journal of Physics. 84(1), 21-25.

Çilesiz, Ş. (2011). A phenomenological approach to experiences with technology: Current state, promise, and future directions for research. Educational Technology Research and Development, 59(4), 487-510. 
Demirci, S., Yılmaz, A ve Şahin, E. (2016). Lise ve üniversite öğrencilerinin atomun yapısı ile ilgili zihinsel modellerine genel bir bakış. Türkiye Kimya Derneği Dergisi Kısım C: Kimya Eğitimi, 1(1), 87-106.

DfCELLS (2008). Science in the national curriculum for Wales. Welsh Assembly Government.

DfE (2013). Science programmes of study: Key stages 1 and 2 National Curriculum in England.

Doug, C. (2010). High school students' perceptions of physics. Unpublished Master Thesis. University of Lethbridge, Canada.

Driver, R. ve Easley, J. (1978). Pupils and paradigms: A review of the literature related to concept development in adolescent science students. Studies in Science Education, 3, 61-84.

Finegold, M. ve Gorsky, P. (1988). Learning about forces: simulating the outcomes of pupils' misconceptions. Instructional Science, 17, 251-261.

Halloun, I.A ve Hestenes, D. (1985). Common sense concepts about motion. American Journal of Physics, 53, 1056-1065.

Harman, G. ve Çökelez, A. (2017). Okul öncesi öğretmen adaylarının kimya, fizik ve biyoloji kavramlarına yönelik metaforik algıları. Marmara Üniversitesi Atatürk Ĕ̆itim Fakültesi Ĕ̆itim Bilimleri Dergisi, 46, 75-95.

Harrison, A. G. ve Treagust, D.F. (1996). Secondary students' mental models of atoms and molecules: Implications. Science Education, 80(5), 509-534.

Karaçam, S. ve Gürsel, Ü. (2017). Lise öğrencilerinin sıvılarda kaldırma kuvveti kavramına yönelik görsel imgeleri ve imgenin kökenleri. Mehmet Akif Üniversitesi Eğitim Fakültesi, 41, 336-345.

Kızılcık, H.S. (2013). Öğretmen adaylarının bazı eş anlamlı fizik terimleri arasındaki tercihlerinin kavramsal algılamayla ilişkisi. Hacettepe Üniversitesi Ĕ̆itim Fakültesi Dergisi, 28(3), 266-278.

Koray, Ö. ve Tatar, N. (2003). İlköğretim öğrencilerinin kütle ve ağırlık ile ilgili kavram yanılgıları ve bu yanılgıların 6., 7. ve 8. Sınıf düzeylerine göre dağılımı. Pamukkale Üniversitesi Eğitim Fakültesi Dergisi, 1(13), 187-198.

Kurt, H. S. ve Sarı, M. (2018). Metaphorical perceptions of physics teacher candidates about some concepts of electricity. Erciyes Journal of Education, 2(1), 64-90.

Kuru, İ. ve Güneş, B. (2005). Lise 2. sinıf öğrencilerinin kuvvet konusundaki kavram yanılgıları. GÜ, Gazi Ĕ̆itim Fakültesi Dergisi, 25(2), 1-17.

Miles, M, B. and Huberman, A. M. (1994). Qualitative data analysis: An expanded Sourcebook. (2nd ed). Thousand Oaks, CA: Sage. 
MEB Fen Bilimleri Dersi Öğretim Programı (İlkokul ve Ortaokul 3, 4, 5, 6, 7, ve 8. siniflar). Ankara (2018).

Muştu, Ö. E. ve Ucer, S. (2018). Ortaokul öğrencilerinin atom kavramına ilişkin bilimsel yapılarının çizim tekniği ile incelenmesi. International Journal of Human Sciences, 15(2), 985-995.

Narjaikaew, P. (2012). Alternative conceptions of primary school teachers of science about force and motion. Social and Behavioral Sciences Symposium, 4th International Science, Social Science, Engineering and Energy Conference 2012 (I-SEEC 2012), Thailand.

Özsevgeç, L. C. Yurtbakan, E. ve Uludüz, Ş. (2019). İlkokul dördüncü sınıf öğrencilerinin "kütle ve ağırlık" kavramlarına yönelik yanılgılarının giderilmesinde kavram karikatürlerinin etkisi. Fen Bilimleri Öğretimi Dergisi, 7(1), 51-67.

Rakbamrung, P., Thepnuan, P. ve Nujenjit N. (2015). Use of a system thinking learning force and motion concept in physics for nurse course. 7th World Conference on Educational Sciences, (WCES-2015), 05-07 February 2015, Novotel Athens Convention Center, Athens, Greece.

Şahin, Ş. (2020). Öğrenci, öğretmen ve müdürlerin sevgi, demokrasi ve öğrenci merkezli eğitim algıları. Yayımlanmamış Yüksek Lisans Tezi. Düzce Üniversitesi, Sosyal Bilimler Enstitüsü, Düzce.

Şimşek, D., Yurtcan, M.T. ve Oktay, Ö. (2019). Fen bilgisi öğretmeni adaylarının kuvvet ve hareket konularındaki kavram yanılgıları. Erzincan Ĕ̆itim Fakültesi Dergisi, 21(3), 195-214.

Turgut, H., Öztürk, N. ve Eş, H. (2017). Üstün zekâlı öğrencilerin bilim ve bilim insanı algısı. Abant İzzet Baysal Üniversitesi Eğitim Fakültesi Dergisi, 17(1), 423-440.

Yalçın, M. ve Erginer, A. (2014). İlköğretim okulu öğrencilerinin okul müdürü algılarına ilişkin yaptıkları çizimler. Eğitim ve Bilim, 39(171), 270-285.

Yaman, E. Akan, R. Doğan ve M. Sarı, Ö. (2019). Illkokul fen bilimleri 4 ders kitabı. Devlet Kitapları 2. Baskı. Milli Eğitim Bakanlığı Yayınları.

Yıldırım, A. ve Şimşek, H. (2008) Sosyal bilimlerde nitel araştırma yöntemleri (6.Baskı). Seçkin Yayınları, Ankara.

Yıldırım, G. ve Gültekin, M. (2017). İlkokul 4. Sınıf fen ve teknoloji dersinde bağlam temelli öğrenme uygulamaları. Ahi Evran Üniversitesi Kırşehir Ĕ̆itim Fakültesi Dergisi, 18, 81-101.

Yürümezoğlu, K. Ayaz, S. ve Çökelez, A. (2009). İlköğretim ikinci kademe öğrencilerinin enerji ve enerji ile ilgili kavramları algılamaları. 
Necatibey Eğitim Fakültesi Elektronik Fen ve Matematik Eğitimi Dergisi, $3(2), 52-73$.

\section{Kaynakça Bilgisi / Citation Information}

Çoramık, M. ve Özdemir, E. (2021). İlkokul öğrencilerinin kuvvet kavramına ilişkin algılarının çizim yardımı ile belirlenmesi. OPUS- Uluslararası Toplum Araştırmaları Dergisi, 18(42), 55165541. DOI: 10.26466/opus.937992. 